\title{
Fracture toughness of RC beams on the shear, strengthening by FRCM system
}

\author{
Zinoviy Blikharskyy ${ }^{1}$, Pavlo Vegera ${ }^{2}$, Rostyslav Vashkevych ${ }^{2}$ and Taras Shnal ${ }^{2}$ \\ ${ }^{1}$ Lviv Polytechnic National University, Department of Bridges and Structural Mechanics, \\ Karpinskogo Str. 6, Lviv, 79013, Ukraine \\ ${ }^{2}$ Lviv Polytechnic National University, Department of Building Constructions and Bridges, \\ Karpinskogo Str. 6, Lviv, 79013, Ukraine
}

\begin{abstract}
This research paper present the experimental study of reinforce concrete beams strengthened by FRCM system in the shear area. All samples are without transverse reinforcement at the shear distance. First beams tested as control sample, with shear distance $\mathrm{a} / \mathrm{d}=2$. Another three beams tested with strengthening by FRCM system. Variable parameter is the level of initial load, before strengthening. The initial load values were $0,0.3,0.5$ from carrying capacity of control samples. All RC beams were designed to fail in shear, even strengthened samples. In the result of this research we determined that fracture toughness of RC beams increases with a decrease of span to the effective depth ratio. Results are comparable with the increasing of bearing capacity. The first inclined crack opend in mid-height cross section at the load $50 \mathrm{kN}$ at an angle equal to $45^{\circ}$ and it does not depend on the shear span. The maximum width of inclined cracks decrease with decreasing of shear span. The maximum width of inclined cracks decrease with decreasing of the shear span. The maximum values of width of inclined cracks are fixed at the value of $0.55-0.85 \mathrm{~mm}$. Using the limit crack opening width as criteria of exhaustion of serviceability (SLS) we saw that about $16-29 \%$ of bearing capacity still remains before the danger of shear failure of the beam.
\end{abstract}

\section{Introduction}

In influence of time, environment and different factors most structures need repairing and strengthening. There are a lot of different type of strengthening. Some of them are jacketing with self-consolidating concrete [1], application of steel plates for and others.

Most popular materials nowadays are different composites called FRP (Fiber Reinforce polymer) or FRCM (Fiber Reinforce Cement Polymers) [2].

There are interest for using different polymer plates for shear strengthening of $\mathrm{RC}$ beams by many researchers $[3,4]$. There are some works with different computer modeling of shear crack [5].

\footnotetext{
* Corresponding author: Pavlo.I.Vehera@lpnu.ua
} 
The goal of this article is to experimentally determine shear strength and serviceability of reinforced concrete beams strengthened with FRCM. Main variable in the experiment was the initial load applied to the beam before strengthening.

\section{The testing program}

Four reinforced concrete beams were tested. All samples are without transverse reinforcement at the shear distance. First beams tested as control sample, with shear distance $\mathrm{a} / \mathrm{d}=2$. Another three beams tested with strengthening by FRCM system. Variable parameter is level of initial load, before strengthening. Initial load was $0,0.3,0.5$ from carrying capacity of control samples. All RC beams were designed to fail in shear, even strengthened samples. For the research, a technique has been developed for testing each beam twice, which was described in our article [8].

Tested beams had $2100 \mathrm{~mm}$ length, $100 \mathrm{~mm}$ width, and $200 \mathrm{~mm}$ height of cross section. As the beam's tension reinforcement, A400C Ø18 mm rebar was chosen, A400C Ø10 mm - as compressed reinforcement. Transverse reinforcement - A240C Ø $6 \mathrm{~mm}$ rebar located in the area without shear force [9].

Concrete class of tested beams was C32/40.

According to the testing program, three specimens were strengthened by reinforcing FRCM system with $70 \mathrm{~mm}$ wide strips (Fig. 1).

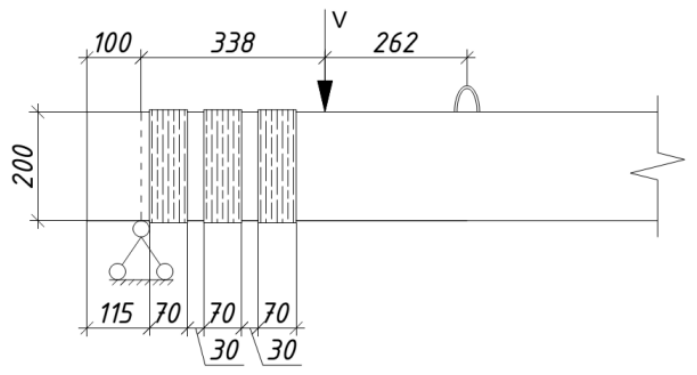

Fig. 1. Scheme of FRCM stripes placement on the RC beams.

Main PBO fibres properties of FRCM stripes are shown in the table 1.

Table 1. Physical and mechanical characteristics of composite fabric stripes RuredilXMeshGold.

\begin{tabular}{|c|c|c|}
\hline № & Characteristics & Value \\
\hline 1 & Density, $\mathrm{g} / \mathrm{cm}^{3}$ & 1,56 \\
\hline 2 & Tensile strength, $\mathrm{MPa}$ & 5800 \\
\hline 3 & Modulus of elasticity, $\mathrm{MPa}$ & 270000 \\
\hline 4 & Ultimate deformation, $\%$ & 2,15 \\
\hline 5 & Equivalent dry fabric thickness in the direction of the warp, $\mathrm{mm}$ & 0,0445 \\
\hline 6 & Equivalent dry fabric thickness in the direction of the weft, $\mathrm{mm}$ & 0,0115 \\
\hline 7 & Ultimate tensile stress of the warp per unit of width, $\mathrm{kN} / \mathrm{m}$ & 264,0 \\
\hline 8 & Ultimate tensile stress of the weft per unit of width, $\mathrm{kN} / \mathrm{m}$ & 66,5 \\
\hline
\end{tabular}

Beams marking were adopted as follows: BO - beam ordinary, BSC - beam strengthened by composite material; the first digit - serial number, the second digit - 
sample number and the third digit - the section number. Index $0-0.5$ means the loading level under which the strengthening was performed and depends on shear strength $\left(\mathrm{V}_{\mathrm{Ed}}\right)$ of non-strengthened control sample. For example, BSC 1.2.2-0.3 means that the tested sample from the first series of the second beam of the second section, with initial load $0.3 \cdot \mathrm{V}_{\mathrm{Ed}}$.

\section{Results of experimental research}

\subsection{The overview of shear failure of beams}

For the RC beam, the limit value of concrete compressed deformation above the inclined crack was taken as the criterion of shear strength (ULS) [Błąd! Nie można odnaleźć źródła odwołania.]. Achievement of limit deformations in transverse reinforcement can not be taken as a criterion for the exhaustion of bearing capacity, because there is a cut of the rebar, which leads to the onset of the yield strength before approaching the limit tensile deformations of the reinforcement.

The bearing capacity of reinforced concrete beams in shear was for BO 1.1 $\mathrm{V}_{\mathrm{Ed}}=95 \mathrm{kN}$, BSC 1.1-0 - $\mathrm{V}_{\mathrm{Ed}}=137.5 \mathrm{kN}$, BSC 1.2-0.3 - $\mathrm{V}_{\mathrm{Ed}}=121.5 \mathrm{kN}$, and for BSC 1.3-0.5 - $\mathrm{V}_{\mathrm{Ed}}=115 \mathrm{kN}$ [Błąd! Nie można odnaleźć źródła odwołania.].

All samples failed in shear. The RC beams after testing are shown in Fig. 2 - 5.

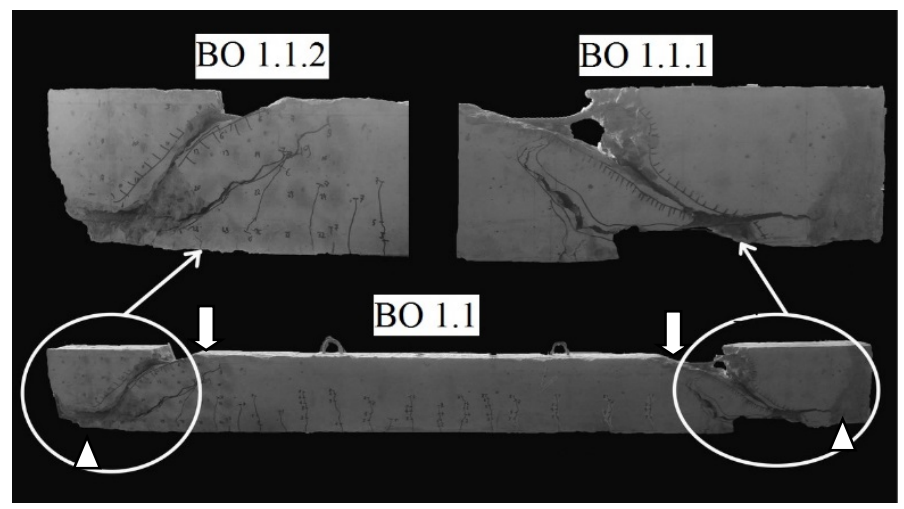

Fig. 2. The tested sample BO 1.1.

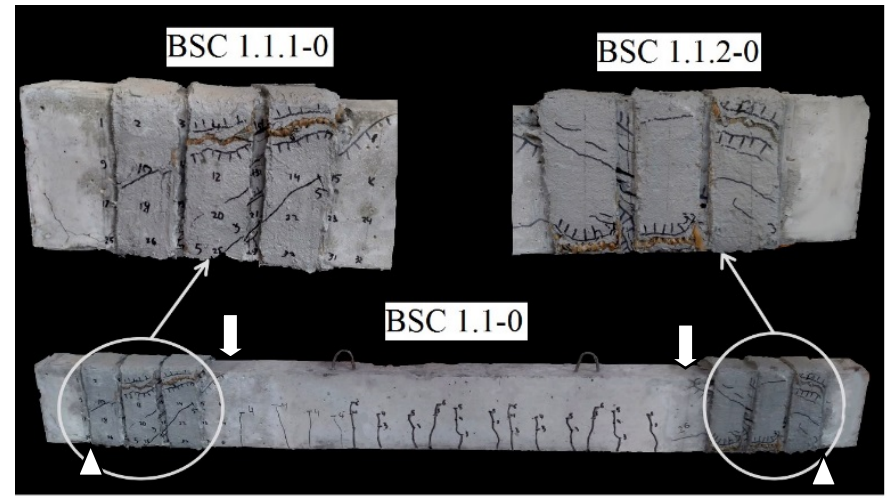

Fig. 3. The tested sample BSC 1.1-0. 


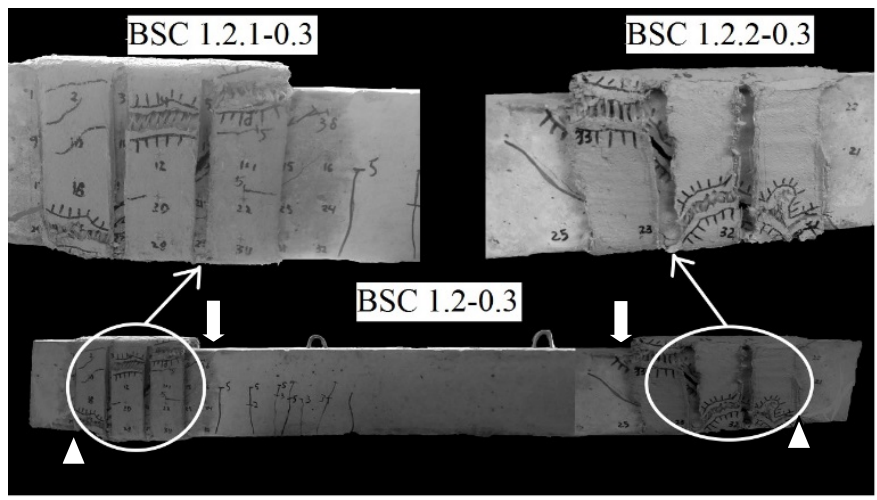

Fig. 4. The tested sample BSC 1.2-0.3.

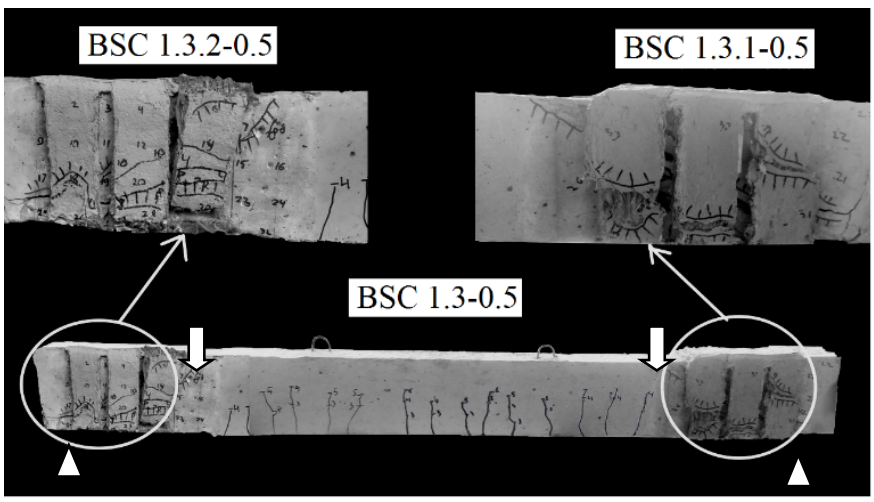

Fig. 5. The tested sample BSC 1.2-0.5.

Exhaustion of the bearing capacity in shear occurred at the time of the destruction of the compressed concrete zone with a sharp extension of the FRCM tape and damage to the protective layer of the FRCM system in the zone of inclined cracks.

\subsection{Fracture toughness in testing samples}

For detailed information about fracture toughness, we measured the width of the crack opening, depth of distribution and location. Width of crack were measured by microscope MBP-3, with accuracy $0.05 \mathrm{~mm}$.

Table 2. The serviceability limit state (SLS) of testing beams on the shear strength.

\begin{tabular}{|c|c|c|c|c|c|}
\hline $\begin{array}{l}\text { Types of the } \\
\text { beam }\end{array}$ & $\begin{array}{l}\text { Types of the } \\
\text { beam's cross } \\
\text { section }\end{array}$ & $\begin{array}{c}\text { Inclined } \\
\text { crack } \\
\text { width, } \\
\text { mm }\end{array}$ & $\begin{array}{c}\text { Experimental } \\
\text { shear } \\
\text { strength, } \\
r_{E d}^{\text {gap }}, \mathbf{k N} \\
\end{array}$ & $\begin{array}{c}\text { Average } \\
\text { experimental } \\
\text { shear } \\
\text { strength, } \\
V_{f i f}^{\text {mit }}, \mathrm{kN}\end{array}$ & 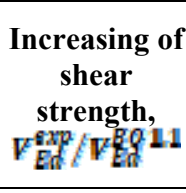 \\
\hline \multirow{2}{*}{ BO 1.1. } & BO 1.1.1 & \multirow{7}{*}{0.4} & 80 & \multirow{2}{*}{80} & \multirow{2}{*}{ - } \\
\hline & BO 1.1.2 & & 80 & & \\
\hline \multirow{2}{*}{ BSC 1.1-0 } & BSC 1.1.1-0 & & 120 & \multirow{2}{*}{110} & \multirow{2}{*}{1.38} \\
\hline & BSC 1.1.2-0 & & 100 & & \\
\hline \multirow{2}{*}{ BSC 1.2-0.3 } & BSC 1.2.1-0.3 & & 100 & \multirow{2}{*}{100} & \multirow{2}{*}{1.25} \\
\hline & BSC 1.2.2-0.3 & & 100 & & \\
\hline BSC $1.3-0.5$ & BSC 1.3.1-0.5 & & 90 & 90 & 1.13 \\
\hline
\end{tabular}


Limit width of crack $\mathrm{w}_{\max }=0.4 \mathrm{~mm}[7,10]$ opened on the level $\mathrm{V}_{\mathrm{Ed}}=80 \mathrm{kN}$ for sample $\mathrm{BO}$ 1.1. BSC 1.1-0 increased serviceability 1.38 times, BSC 1.2-0.3 - 1.25 times, and BSC 1.3$0.5-1.13$ times. Rapidly decreas of serviceability for BSC 1.3-0.5 caused by strengthening after opening of the first inclined crack.

The boundary values of the crack opening width are fixed at $78-84 \%$ of the load carrying capacity of the samples (Table 3 ).

Using the limit crack opening width as criteria of exhaustion of the serviceability (SLS) we determined that the beam still has $16-22 \%$ reserve of bearing capacity, before the danger of shear failure of the beam. Bearing capacity reserve for all samples are in one range and are close to the value of control beam.

Table 3. The comparison of testing beams in shear.

\begin{tabular}{|c|c|c|c|c|c|}
\hline $\begin{array}{l}\text { Types of the } \\
\text { beam }\end{array}$ & $\begin{array}{l}\text { Types of the } \\
\text { beam's cross } \\
\text { section }\end{array}$ & $\begin{array}{c}\text { Inclined } \\
\text { crack } \\
\text { width, } \\
\text { mm }\end{array}$ & $\begin{array}{c}\text { Average } \\
\text { experimental } \\
\text { shear } \\
\text { strength, } \\
V_{E d}^{\text {fap }}, \mathrm{kN}\end{array}$ & $\begin{array}{c}\text { Average } \\
\text { experimental } \\
\text { shear } \\
\text { strength by } \\
\text { SLS, } \\
\text { With, kN }\end{array}$ & $\begin{array}{c}\text { Increasing } \\
\text { of shear } \\
\text { strength, } \\
F_{E S S / F_{E d}^{\text {sax }}}\end{array}$ \\
\hline \multirow{2}{*}{ BO 1.1. } & BO 1.1.1 & \multirow{8}{*}{0.4} & \multirow{2}{*}{95} & \multirow{2}{*}{80} & \multirow{2}{*}{0.84} \\
\hline & BO 1.1.2 & & & & \\
\hline \multirow{2}{*}{ BSC $1.1-0$} & BSC 1.1.1-0 & & \multirow{2}{*}{137.5} & \multirow{2}{*}{110} & \multirow{2}{*}{0.80} \\
\hline & BSC 1.1.2-0 & & & & \\
\hline \multirow{2}{*}{ BSC $1.2-0.3$} & BSC 1.2.1-0.3 & & \multirow{2}{*}{121.5} & \multirow{2}{*}{100} & \multirow{2}{*}{0.82} \\
\hline & BSC 1.2.2-0.3 & & & & \\
\hline \multirow{2}{*}{ BSC $1.3-0.5$} & BSC 1.3.1-0.5 & & \multirow{2}{*}{115} & \multirow{2}{*}{90} & \multirow{2}{*}{0.78} \\
\hline & BSC 1.3.2-0.5 & & & & \\
\hline
\end{tabular}

Values of maximum crack opening are described in the table 4.

Table 4. Maximum inclined crack opening width of testing beams.

\begin{tabular}{|c|c|c|c|c|c|c|}
\hline $\begin{array}{l}\text { Types of the } \\
\text { beam }\end{array}$ & $\begin{array}{l}\text { Types of the } \\
\text { beam's cross } \\
\text { section }\end{array}$ & $\begin{array}{c}\text { Shear } \\
\text { strength, } \\
V_{E d}, \mathbf{k N}\end{array}$ & $\begin{array}{c}\text { Inclined } \\
\text { crack } \\
\text { width (in } \\
\text { concrete), } \\
\text { mm }\end{array}$ & $\begin{array}{c}\text { Average } \\
\text { inclined } \\
\text { crack } \\
\text { width, } \\
\text { mm }\end{array}$ & $\begin{array}{c}\text { Inclined } \\
\text { crack } \\
\text { width } \\
\text { (in } \\
\text { FRCM), } \\
\text { mm }\end{array}$ & $\begin{array}{c}\text { Average } \\
\text { inclined } \\
\text { crack } \\
\text { width, } \\
\text { mm }\end{array}$ \\
\hline \multirow{2}{*}{ BO 1.1. } & BO 1.1.1 & 90 & 0.80 & \multirow{2}{*}{0.85} & - & \multirow[b]{2}{*}{-} \\
\hline & BO 1.1.2 & 90 & 0.90 & & - & \\
\hline \multirow{2}{*}{ BSC 1.1-0 } & BSC 1.1.1-0 & 130 & 0.50 & \multirow{2}{*}{0.55} & 0.25 & \multirow{2}{*}{0.30} \\
\hline & BSC 1.1.2-0 & 140 & 0.60 & & 0.35 & \\
\hline \multirow{2}{*}{ BSC 1.2-0.3 } & BSC 1.2.1-0.3 & 120 & 0.60 & \multirow{2}{*}{0.55} & 0.20 & \multirow{2}{*}{0.17} \\
\hline & BSC 1.2.2-0.3 & 115 & 0.50 & & 0.15 & \\
\hline \multirow{2}{*}{ BSC $1.3-0.5$} & BSC 1.3.1-0.5 & 110 & 0.70 & \multirow{2}{*}{0.67} & 0.15 & \multirow{2}{*}{0.15} \\
\hline & BSC 1.3.2-0.5 & 110 & 0.65 & & 0.15 & \\
\hline
\end{tabular}

Maximum crack opening in FRCM strengthening system are 2 times less than crack width in the concrete for beam BSC 1.1-0. In this sample maximum level of strengthening, increased serviceability were achived, so the maximum width of inclined crack in FRCM system and concrete is at the shear distance. For another two beams, width of crack opening is on the same level, lower than for BSC 1.1-0. 
However, maximum width of crack opening does not exceed limit value. In contradiction to crack in concrete, there are more cracks in the FRCM system.

\section{Conclusion}

Based on the data above, the following conclusions can be drawn:

1. The beam still has $16-22 \%$ reserve of bearing capacity, before the danger of shear failure of the beam.

2. Maximum crack opening in FRCM strengthening system are 2 times and more less than crack width in the concrete.

3. Bearing capacity reserve for all samples are in one range and are close to the value of control beam.

4. Maximum width of crack opening in the FRCM system does not exceed limit value.

\section{References}

1. T. Greenough, M. Nehdi, Shear Behavior of Fiber-Reinforced Self-Consolidating Concrete Slender Beams (ACI Mat. J., 2008)

2. A. Dasgupta, Retrofitting of Concrete Structure with Fiber Reinforced Polymer (IJIRST, 2018)

3. R. Azam., K. Soudki, J.S. West, M. Noël, Strengthening of shear-critical RC beams: Alternatives to externally bonded CFRP sheets (Const. and Buld. Mat. 2017)

4. H. Al-Ghanim, A. Al-Asi1, M. Abdel-Jaber, M. Alqam, Shear and Flexural Behavior of Reinforced Concrete Deep Beams Strengthened with CFRP Composites (Mod. Appl. Sc., 2017)

5. S. Shahbazpanahi, Mechanical analysis of a shear-cracked RC beam (Acta Sc. Tech., 2017)

6. National Standard of Ukraine, Concrete and reinforced concrete structures (DBN B.2.6 - 98: 2009, 84, 2011)

7. Eurocode 2: Design of concrete structures - Part 1-1: General rules for buildings (EN 1992-1-1:2004 (E), 225, 2004)

8. P. Vegera, R. Khmil, Z. Blikharskyy, SCTP, 823, 38 (2015)

9. P. Vegera, R. Vashkevych, R. Khmil, Z. Blikharskyy, SSP, 12(2), 39 (2017).

10. National Standard of Ukraine, Concrete and reinforced concrete structures (DBN B.2.6 - 98: 2009, 84, 2011) 